\title{
Occult Hepatitis C Virus Infection in Hemodialysis Patients; Single Center Study
}

\author{
Samya El-shishtawy ${ }^{1}$, Nevine Sherif ${ }^{1}$, Emad Abdallh ${ }^{1}$, Laila Kamel ${ }^{2}$, Mohamed Shemis ${ }^{3}$, Abdel Aziz Ali \\ Saleem ${ }^{4}$, Haitham Abdalla ${ }^{4}$, Hesham Gamal el Din ${ }^{5}$
}

\footnotetext{
${ }^{1}$ Nephrology Department, Theodor Bilharz Research Institute, Giza, Egypt

${ }^{2}$ Clinical Pathology Department Theodor Bilharz Research Institute, Giza, Egypt

${ }^{3}$ Biochemistry Department, Theodor Bilharz Research Institute, Giza, Egypt

${ }^{4}$ Department of Tropical Diseases, Theodor Bilharz Research Institute, Giza, Egypt

${ }^{5}$ Clinical Pathology Department National Research Center, Giza, Egypt
}

\section{Type of article: Original}

\begin{abstract}
Introduction: A new form of hepatitis $\mathrm{C}$ virus infection, known as occult hepatitis $\mathrm{C}$ virus (HCV) infection, is characterized by the presence of HCV RNA in the liver or peripheral blood mononuclear cells (PBMCs). However, no serological markers of infection occur and there is not as much damage to the liver damage as is produced by chronic hepatitis $\mathrm{C}$. There is a high incidence of $\mathrm{HCV}$ infection among hemodialysis patients, there is significant concern about viral transmission. HCV infection is a major problem in hemodialysis (HD) units even though blood products are screened for anti-HCV antibodies and other precautions are taken. The aim of this study was to determine the prevalence of occult HCV infection in PBMC in chronic hemodialysis (CHD) patients in the dialysis unit at Theodor Bilharz Research Institute (TBRI) with HCV antibodies and HCV RNA negativity irrespective of their liver function tests.

Methods: Fifty-three patients who were repeatedly were anti-HCV negative and serum HCV-RNA negative and on regular hemodialysis for $>$ six months were enrolled in the study, which was conducted in the dialysis unit of Nephrology Department at TBRI; there were 10 healthy matched controls. The patients were classified into two groups according to the result HCV RNA in their PBMCs. Serological markers of HCV infection, including antiHCV antibody and serum HCV-RNA, were repeatedly negative for all patients included in the study. We collected serum and PBMC samples from the patients on the day they entered the study. The test of all serum samples for anti-HCV antibodies and HCV-RNA was repeated by RT-PCR to ensure that the patients did not have these HCV serologic markers, We also measured their ALT and GGT levels.

Results: Occult hepatitis C virus infection (OCI) was detected in $15.1 \%$ of our CHD patients without any evidence of chronic liver disease.

Conclusion: Occult HCV infection was present among the hemodialysis patients irrespective of whether they had persistent abnormal values of liver enzymes for which no cause had been identified. Further study is required to determine the clinical significance of occult $\mathrm{HCV}$ infections in these patients.

Keywords: hepatitis C, hemodialysis, occult infection
\end{abstract}

\section{Introduction}

Chronic infection with hepatitis $\mathrm{C}$ virus (HCV) is a serious public health problem associated with increased morbidity and mortality, and it affects approximately $2.8 \%$ of the world's population $(1,2)$. The distribution of this infection varies significantly between various geographical locations (3). It was found that about $20 \%$ of Egypt's population had HCV infections, the highest prevalence anywhere in the world (4). The International Committee on Taxonomy of Viruses has classified hepatitis $\mathrm{C}$ virus as being within the genus Hepacivirus, family Flaviviridae. Six major phenotypes (HCV-1 to HCV-6) have been described, each of which contains multiple subtypes with different

\section{Corresponding author:}

Dr. Samya Hassan El-shishtawy, Lecturer of Internal Medicine, Nephrology Department, Theodor Bilharz Research Institute, Giza, Egypt. Tel: +20.1003661563 Samya_shishtawy@yahoo.com

Received: September 06, 2015, Accepted: October 09, 2015, Published: December 2015

iThenticate screening: October 22, 2015, English editing: November 03, 2015, Quality control: November 08, 2015

(C) 2015 The Authors. This is an open access article under the terms of the Creative Commons Attribution-NonCommercialNoDerivs License, which permits use and distribution in any medium, provided the original work is properly cited, the use is non-commercial and no modifications or adaptations are made. 
distributions in different regions of the world (5). Currently, HCV is diagnosed by the detection of anti-HCV (antibody against HCV) and HCV-RNA in serum (2-6). Interestingly, in recent years, HCV-RNA has been detected in non-serum reservoirs, such as peripheral blood mononuclear cells (PBMCs) and/or hepatocytes even in the absence of HCV RNA in serum, which has raised the controversial issue of an intriguing, but not unequivocally accepted, entity designated as "occult HCV infection'" (7, 8). The virus' replicating ability in PBMCs could possibly lead to the spread of $\mathrm{HCV}$, and patients with occult HCV may be potentially infectious (9). Occult HCV infection in liver tissue/PBMCs has been described in two clinical settings: 1) Seronegative OCI: In patients with liver disease of unknown origin (anti-HCV-negative, serum HCV RNA negative, persistently elevated liver transaminases) $(7,10,11)$ and 2) Seropositive OCI: In patients with spontaneous/treatment-induced HCV RNA clearance from serum (anti-HCV-positive, serum HCV RNA-negative, normal liver transaminases) (12, 13). Recently, occult HCV infection also was reported in an apparently disease-free state in the absence of liver disease, anti-HCV, or HCV-RNA in serum $(14,15)$.

PBMCs represent an extra-hepatic site for the replication of $\mathrm{HCV}$. The viral replication involves synthesis of a negative strand of antigenomic or complementary RNA, which facilitates the production of a positive strand of RNA (genomic RVA strand). An active viral replication is indicative of a negative RNA strand (16). It was hypothesized that if HCV RNA does persist at low levels in PBMCs, then it should be more easily detectable in patients with impaired immune function, such as those on chronic hemodialysis (CHD) and kidney transplant (KTx) recipients than in immunocompetent patients (17). Therefore, these patients would constitute an ideal model to explore the existence of occult HCV infection, all the more so as the presence of occult HCV infection may have deleterious consequences in these high-risk groups of patients (9). HCV infection reduces the rate of survival among patients who are on maintenance dialysis and after renal transplantation (18). In this study, we aimed to determine the prevalence of occult HCV infection in PBMCs in chronic hemodialysis (CHD) patients in the dialysis unit at Theodor Bilharz Research Institute (TBRI) with HCV antibodies and HCV-RNA negativity irrespective of their liver function, since serum enzymes may be normal in these patients even in the presence of liver disease.

\section{Material and Methods}

\subsection{Study setting and ethics}

This study was conducted in the dialysis unit of Theodor Bilharz Research Institute in 2015. Fifty-three patients who were repeatedly anti-HCV and serum HCV-RNA negative and on regular hemodialysis for three sessions weekly, four hours each, for a period $>6$ months were enrolled in the study. In addition 10 healthy volunteers from medical and paramedical subjects who had normal liver function tests and were repeatedly negative for anti-HCV antibody and HCV-RNA in serum were used as negative controls. Regarding the research ethics, informed written consents were obtained from all patients according to the Declaration of Helsinki.

\subsection{Inclusion and exclusion criteria}

The inclusion criteria were end-stage renal disease and regular hemodialysis for at least six months. The exclusion criteria were 1) evidence of acute or chronic HBV infection (determined by positive HBsAg), 2) patients who had been vaccinated against $\mathrm{HBV}, 3$ ) other causes of liver dysfunction, such as autoimmune hepatitis, toxic hepatitis, primary biliary cirrhosis, alcohol abuse, and metabolic disorders, and 4) patients who were being treated with interferon and/or ribavirin.

\subsection{General diagnostic methods}

After taking their full histories and conducting clinical examinations, all patients and controls in this study were subjected to the following: complete blood picture (CBC), kidney functions and liver enzymes (ALT and GGT), RNA Extraction from Serum and PBMCs, serum creatinine and ALT were performed by conventional methods using Beckman Coulter Synchron CX5 Pro, chemistry auto analyzer, Serum GGT was assayed using Human kits (Human Diagnostics, Manheim, Germany), and anti-HCV was tested using commercially available Elisa kits (Diasorin, Torino, Italy).

\subsection{Peripheral blood mononuclear cells (PBMCs) isolation}

PBMCs were separated on Ficoll-Histopaque density gradients (Sigma-Aldrich Co., St Louis, MO, USA) according to the manufacturer's protocol, (Thimme R, Bukh J, Spangenberg HC, et al. Viral and immunological determinants of hepatitis C virus clearance, persistence, and disease. Proc Natl Acad Sci U S A. 2002;99(24):15661-15668.) with minor modifications. PBMCs were separated from $3 \mathrm{~mL}$ of fresh EDTA venous blood using centrifugation on a 
Ficoll-Histopaque gradient at $2200 \mathrm{rpm}$ for 30 minutes. The PBMC layer was separated and washed three times with $1 \times$ phosphate buffered saline (PBS) with a pH of 7.4 at $2200 \mathrm{rpm}$ for 10 minutes. The cells were resuspended in $1 \mathrm{x}$ PBS, and they were stored at $-80{ }^{\circ} \mathrm{C}$ until used.

\subsection{Total RNA extraction from PBMCs and plasma}

Total RNA from the PBMC cell suspension/plasma was extracted following the protocol developed by Chomczynski and Sacchi (Chomczynski P, Sacchi N. The single-step method of RNA isolation by acid guanidinium thiocyanate-phenol-chloroform extraction: twentysomething years on. Nat Protoc. 2006;1(2):581-585) using Tri Reagent (Molecular Research Center, Inc., Cincinnati, OH, USA). Briefly, $1 \mathrm{~mL}$ of Tri Reagent was placed into an Eppendorf tube, and $200 \mu \mathrm{L}$ of a well-mixed suspension of PBMCs /plasma were added. The tubes were shaken for a few seconds and kept at near-room temperature for five minutes; then, $100 \mu \mathrm{L}$ of bromochloropropane (BCP) were added. After adding the $\mathrm{BCP}$, the tubes were shaken for 15 seconds and stored for two to 15 minutes. The tubes were centrifuged at $14,000 \mathrm{rpm}$ at $4{ }^{\circ} \mathrm{C}$ for 15 minutes. The aqueous phase was added to a new Eppendorf tube and mixed with $500 \mu \mathrm{L}$ of isopropanol and stored for 5 to 10 minutes. The tubes were centrifuged again at 14,000 rpm for eight minutes at 4 to $25^{\circ} \mathrm{C}$, and the supernatant was removed from the tubes; then, the RNA pellet was washed with $1 \mathrm{~mL}$ of $75 \%$ ethanol. The tubes were centrifuged at $8,000 \mathrm{rpm}$ for five minutes at room temperature, and the attached ethanol drops were removed by air drying the RNA pellet for three to five minutes. The remaining ethanol was discarded using a pipette tip. The RNA pellet was resuspended in $30 \mu \mathrm{L}$ of diethylpyrocarbonate in distilled water by mixing with a pipette. The tubes were incubated for 10 to 15 minutes at 55 to $60{ }^{\circ} \mathrm{C}$. Then, $1 \mu \mathrm{L}$ of dissolved RNA was mixed with $99 \mu \mathrm{L}$ of distilled water.

\subsection{Detection of Genomic and Antigenomic HCV-RNA in PBMCs and plasma by Reverse Transcription nested PCR (RT-PCR)}

Both the positive and negative strands of HCV RNA were detected by strand-specific RT-PCR using an oligonucleotide primers chosen from the highly conserved $5^{\prime}$ noncoding $\left(5^{\prime} \mathrm{NC}\right)$ region of the HCV genome (I Castillo, E Rodríguez-Iñigo, J Bartolomé, S de Lucas, N Ortíz-Movilla, J M López-Alcorocho, M Pardo, and V Carreño, Hepatitis $\mathrm{C}$ virus replicates in peripheral blood mononuclear cells of patients with occult hepatitis $\mathrm{C}$ virus infection, Gut. 2005 May; 54(5): 682-685). Strand-specific RT-PCR reaction was carried in a total volume of $100 \mu 1$ containing $30 \mu \mathrm{l}$ of the extracted RNA, 1X Taq buffer with $1.5 \mathrm{mM} \mathrm{MgCl} 2$ (Promega Madison, WI, USA), $0.2 \mathrm{mM}$ dNTPs (Promega Madison, WI, USA), 20 pmole of either the sense or antisense primer, 20 units of RNasin (Promega Madison, WI, USA), 10 units of AMV Reverse Transcriptase (RT) (Promega Madison, WI, USA), and 2.5 units Taq DNA polymerase (Promega Madison, WI, USA). The mixture was incubated at $42{ }^{\circ} \mathrm{C}$ for 30 min for RT, $95^{\circ} \mathrm{C}$ for $5 \mathrm{~min}$, followed by 35 cycles at $94{ }^{\circ} \mathrm{C}$ for 30 seconds, $55^{\circ} \mathrm{C}$ for 30 seconds, and $72{ }^{\circ} \mathrm{C}$ for one minute, followed by a final extension at $72{ }^{\circ} \mathrm{C}$ for seven minutes.

Genomic HCV-RNA in plasma was detected by a single tube RT-PCR as previously described except that both sense and antisense primers were added simultaneously to the RT-PCR mixture. For the nested PCR reaction, $5 \mu$ of the first PCR products were added to the second nested PCR and amplified for another 30 cycles, using inner forward and reverse primers. All PCR reactions were carried out on Bio-Rad T100 Thermal cycler. PCR products (266 bp) were visualized by $1.5 \%$ agarose gel electrophoresis. HCV-RNA positive and negative controls were included in each PCR run. As negative controls, we used PBMCs from healthy volunteers who had normal liver function tests and were repeatedly HCV-RNA negative in PBMCs. To confirm the results of different runs of PCR amplification to exclude the occurrence of contamination, all positive samples were retested. The sensitivity limit of the PCR amplification method for detection of genomic HCV RNA strand was $45 \mathrm{IU} / \mathrm{ml}$ plasma. The sensitivity was determined by testing serial dilutions of a plasma specimen with a known viral load [determined using Abbott Real Time HCV assay (Abbott Molecular Inc., Des Plaines, IL).

\subsection{Statistical Analysis}

Results were expressed as mean \pm standard deviation of the mean (SD) or number (\%). Comparison between different parameters in the two studied groups was performed using the unpaired t-test. Comparison between parameters in different pathological classes was performed using ANOVA. Comparison between categorical data was performed using the chi-squared test. Correlation between different parameters in the cases group was performed using the Pearson correlation. The data were considered significant if the $\mathrm{p}$ value were equal to or less than 0.05 and highly significant if the $p$ value $<0.01$. Statistical analysis was performed using SPSS software (version 12 for Windows). 


\section{Results}

The demographic features and clinical data of all patients and control group are summarized in Table 1 . There were differences between the two groups that were highly statistically significant regarding age, gender, haemoglobin, and creatinine $(\mathrm{p}<0.001)$. There were no statistically significant differences between the two groups regarding ALT and GGT. Primary kidney disease in HD patients is shown in Table 2. Hypertension was the most common disease at $49.1 \%$, and it was followed by diabetes $(9.4 \%)$, and obstructive uropathy (7.5\%). Unknown causes of kidney disease were $11.3 \%$. Virological results in both HD patients and control subjects are shown in Table 3. Out of 53 patients who underwent regular hemodialysis, eight patients $(15.1 \%)$ had positive HCV RNA in PBMCs (occult $\mathrm{HCV}$ infections). Comparison between PBMNs negative cases and positive cases are shown in Table 4. There were no statistically significant differences between the two groups regarding mean values of ALT, GGT, duration of hemodialysis, history of blood transfusion, or family history of HCV. Replication was detected in five positive cases $(62.5 \%)$.

Table 1. Demographic features and clinical data of all patients and controls

\begin{tabular}{|c|c|c|c|c|}
\hline \multirow{3}{*}{ Age } & & Control $(\mathrm{n}=10)$ & HD patients $(\mathrm{n}=53)$ & p-value \\
\hline & Range & $22.0-45.0$ & $19.0-83.0$ & \\
\hline & Mean \pm SD & $37.10 \pm 7.68$ & $54.79 \pm 13.03$ & 0.001 \\
\hline \multicolumn{2}{|l|}{ Gender (F/M) } & $10 / 0(100 \% / 0 \%)$ & $18 / 35(34.0 \% / 66.0 \%)$ & 0.001 \\
\hline \multirow[t]{2}{*}{ Duration of disease (yrs.) } & Range & ---- & $1.5-10.0$ & \\
\hline & Mean \pm SD & ---- & $3.95 \pm 1.93$ & \\
\hline \multicolumn{2}{|c|}{ History of blood transfusion } & $\begin{array}{ll}-- \\
\end{array}$ & $31(58.5 \%)$ & \\
\hline \multicolumn{2}{|l|}{ Family history } & --- & $9(17.3 \%)$ & \\
\hline \multirow[t]{2}{*}{ S. ALT (IU/ml) } & Range & $7.0-33.0$ & $6.0-67.0$ & \\
\hline & Mean \pm SD & $13.00 \pm 7.57$ & $17.66 \pm 11.31$ & 0.070 \\
\hline \multirow[t]{2}{*}{ S. GGT (IU/ml) } & Range & $12.0-45.0$ & $11.0-256.0$ & \\
\hline & Mean \pm SD & $23.20 \pm 10.41$ & $44.38 \pm 43.89$ & 0.098 \\
\hline \multirow[t]{2}{*}{ Hemoglobin (g/dl) } & Range & $10.0-14.0$ & $8.0-14.0$ & \\
\hline & Mean \pm SD & $11.75 \pm 1.02$ & $10.04 \pm 1.24$ & 0.001 \\
\hline \multirow[t]{2}{*}{ Creatinine $(\mathrm{mg} / \mathrm{dl})$} & Range & $0.6-1.1$ & $6.4-11.4$ & \\
\hline & Mean \pm SD & $0.86 \pm 0.14$ & $8.13 \pm 1.29$ & 0.001 \\
\hline \multicolumn{2}{|c|}{ Serum HCV RNA by PCR } & $0(0 \%)$ & $0(0 \%)$ & \\
\hline \multicolumn{2}{|c|}{ HCV- RNA in PBMCs by PCR } & --- & $8(15.1 \%)$ & \\
\hline
\end{tabular}

Data are expressed as mean $\pm \mathrm{SD}$, minimum and maximum or number $(\%)$

Table 2. Primary kidney disease in HD patients

\begin{tabular}{|l|l|l|}
\hline Variables & $\mathrm{n}$ & $\%$ \\
\hline Analgesic nephropathy & 2 & 3.8 \\
\hline DM & 5 & 9.4 \\
\hline DM HTN & 5 & 9.4 \\
\hline GN & 3 & 5.7 \\
\hline HTN & 26 & 49.1 \\
\hline Obstructive uropathy & 4 & 7.5 \\
\hline Polycystic kidney & 1 & 1.9 \\
\hline Recurrent stone & 1 & 1.9 \\
\hline Unknown & 6 & 11.3 \\
\hline
\end{tabular}

Table 3. Virological results in both HD patients and control subjects

\begin{tabular}{|l|l|l|}
\hline & Control $(\mathrm{n}=10)$ & HD patients $(\mathrm{n}=53)$ \\
\hline Serum anti- HCV Abs & $0(0 \%)$ & $0(0 \%)$ \\
\hline Serum HCV RNA by PCR & $0(0 \%)$ & $0(0 \%)$ \\
\hline HCV RNA in PBMCs by PCR & ----- & $8(15.1 \%)$ \\
\hline
\end{tabular}

Data are expressed as number (\%). 
Table 4. Comparison between mean values of ALT, GGT, and others in the HD groups classified according to PBMNs' positivity

\begin{tabular}{|l|l|l|l|}
\hline & PBMNs negative $(\mathrm{n}=45)$ & PBMNs positive $(\mathrm{n}=8)$ & $\mathrm{p}$-value \\
\hline ALT $(\mathrm{IU} / \mathrm{ml})$ & $15.0(6.0-67.0)$ & $12.5(9.0-21.0)$ & 0.179 \\
\hline GGT $(\mathrm{IU} / \mathrm{ml})$ & $28.0(11.0-256.0)$ & $28.5(17.0-88.0)$ & 0.990 \\
\hline Duration of hemodialysis (years) & $4.0(1.5-10.0)$ & $2.5(1.5-5.0)$ & 0.067 \\
\hline History of blood transfusion & $26(57.8 \%)$ & $5(62.5 \%)$ & 0.803 \\
\hline Family history HCV & $7(15.6 \%)$ & $2(28.6 \%), \mathrm{n}=7$ & 0.397 \\
\hline Replication & --- & $5(62.5 \%)$ & --- \\
\hline
\end{tabular}

Data are expressed as median (minimum-maximum) or number $(\%)$

\section{Discussion}

We know very little about the prevalence of occult HCV infection, its natural history, potential transmission risk, and its impact in the general population. In the absence of serological markers of HCV, HCV-RNA has been detected in PBMCs almost exclusively in patients with liver disease or in immunosuppressed patients $(7,10,19)$. However, information about occult HCV infection in patients on maintenance dialysis is limited (20). The patients undergoing CHD are at an increased risk for exposure due to vascular access, blood transfusions, and the potential for nosocomial transmission (6). The existence of occult $\mathrm{HCV}$ infection may potentially have significant consequences for these populations. These include the risk for nosocomial transmission of the virus within hemodialysis units (21). Therefore, detection of occult HCV infection not uncovered by routine diagnostic methods may have an important bearing on the development of new screening strategies and therapeutic interventions for $\mathrm{HCV}$ infection in these patients. The original report of occult HCV infection in all HD patients with HCV-RNA in PBMC indicated that they also must have viral RNA in their liver (7). A patient who had occult HCV infection and underwent a liver biopsy verified the validity of the report. Even so, the detection of HCV-RNA in PBMC does not identify all cases with occult HCV. This means that some of the HD patients without viral RNA in PBMC could have occult HCV infections in their livers; however, it is not routinely recommended that HD patients have liver biopsies except in cases of renal transplant candidates before they begin their anti-viral therapy. So, according to this, the cases of elevated liver enzymes without the detection of HCV-RNA in PBMCs may have viral RNA in the liver cells (10).

There were 53 patients in this study, and all of them had negative anti-HCV antibodies in their serum and negative HCV RNA by real time PCR in their serum. We detected HCV-RNA in PBMCs in eight of 53 cases (15.1\%) without any evidence of liver disease. These results are similar to those in one of the earliest studies of patients on CHD in which HCV genome was detected in PBMCs in approximately 9\% of 67 patients without any evidence of liver disease and without the presence of viremia or serological markers in the serum (22). In another study, the persistence of HCV RNA in PBMCs was reported in two of 11 CHD patients (18\%) despite negative HCV-RNA in their serum (20). In our study, there was no statistical difference between positive and negative HCV RNA in PBMCs regarding the liver enzymes ALT and GGT (p-values were 0.179 and 0.990 , respectively), indicating that liver enzymes may not be elevated in occult HCV-infected patients, which may be attributed to uremia and low immunity in these patients. In contrast to our study, in a large study with 103 patients CHD patients, occult HCV infection in PBMCs was found in up to $45 \%$ of investigated patients with abnormal liver enzyme levels of unknown etiology (10).

Since antigenomic HCV RNA was detected in five HD patients with occult HCV, HCV was replicated within PBMCs, and this suggested that these patients potentially could be infectious. However, the existence of occult HCV infection is not excluded by negativity for HCV- RNA in PBMCs, because the gold standard method to identify this occult infection is by detecting viral RNA in liver cells (10). Regarding the duration of HD in our study, there was no statistical difference between the two groups even though another study showed that the duration was significantly longer in patients with occult HCV infections (10). In PBMC positive patients, five (62.5\%) patients had histories of blood transfusions, while in the negative group, only $26(57.8 \%)$ had histories of blood transfusions. Among the clinical consequences of occult HCV infection, there is the risk for the transmission of HCV in HD units by patients with occult HCV. However, from a theoretical perspective, we cannot exclude the nosocomial spread of occult HCV among HD patients. The low incidence of de novo HCV in patients who undergo maintenance HD in the developed world likely is due to the screening of blood donors for anti-HCV antibody as well as the implementation of infection control precautions (23). A Belgian multicenter study showed that full implementation of infection control procedures to prevent transmission of blood-borne pathogens, including HCV, could reduce the 
annual incidence of seroconversion from 1.4 to $0.0 \%(23)$. The current measures to control the spread of HCV, although they do not incorporate routine PCR or nucleic acid technology, should be adequate if occult HCV infection does transmit HCV within dialysis units. However, more information is needed about occult HCV in this setting due to the existing experience with the transmission of $\mathrm{HBV}$ infections in renal transplant recipients from donors with HBV serologies indicative of a previous infection. Further information is needed to define the risk, if any, for $\mathrm{HCV}$ transmission from donors with occult $\mathrm{HCV}$ to uninfected recipients. The reactivation of $\mathrm{HCV}$ after renal transplantation in recipients with occult $\mathrm{HCV}$ is another theoretical concern, because immunosuppressive therapy enhances HCV replication in organ-transplant recipients (21). The existence of occult HCV infection was described in a recent study among healthy people with normal alanine aminotransferase and normal aminotransferase values (14). The subjects were tested for anti-HCV and for HCV RNA in plasma and in PBMCs, and all were anti-HCV and serum HCV RNA negative; however, viral RNA was detected in the PBMCs of nine of the 276 healthy controls $(3.3 \%)$ with normal liver enzymes. This indicated that there is a potential risk for spreading $\mathrm{HCV}$ by a healthy population with occult HCV (24). Thus, in blood donations, the efficacy of reducing the risk of transmitting viruses is still being debated even though there are approaches available to reduce the risk of leukocyterelated disease, such as leukodepletion (25). Potentially, healthy blood donors could have HCV-RNA in their serum that cannot be detected using conventional PCR assays. Thus, blood donors with occult HCV infection potentially could transmit this infection since it cannot be detected by current screening tests for HCV (25). Therefore, additional study of healthy subjects with normal liver enzymes should be conducted, especially among blood donors, to determine definitively the possible magnitude of this infection.

\section{Conclusions}

Hemodialysis patients who have or do not have persistently abnormal liver enzyme values for unknown reasons may have occult HCV infections. Thus, further study is needed to determine the clinical significance of occult HCV infections. For this reason, concern about HCV transmission in hemodialysis units has increased in recent years.

\section{Acknowledgments:}

The authors thank the Theodor Bilharz Research Institute for supporting the study.

\section{Conflict of Interest:}

There is no conflict of interest to be declared.

\section{Authors' contributions:}

All authors contributed to this project and article equally. All authors read and approved the final manuscript.

\section{References}

1) Mohd Hanafiah K, Groeger J, Flaxman AD, Wiersma ST. Global epidemiology of hepatitis C virus infection: new estimates of age-specific antibody to HCV seroprevalence. Hepatology. 2013; 57:1333-42. doi: 10.1002/hep.26141, PMID: 23172780.

2) Moyer VA. Screening for hepatitis C virus infection in adults: u.s. preventive services task force recommendation statement. Ann Intern Med. 2013;159: 349-57. doi: 10.7326/0003-4819-159-5201309030-00672, PMID: 23798026.

3) Alter MJ. Epidemiology of hepatitis C virus infection. World J Gastroentrol. 2007; 7;13(17): 2436-41. doi: 10.3748/wjg.v13.i17.2436.

4) Reker C, Islam KM. Risk factors associated with high prevalence rate of hepatits C infection in Egypt. Int J Infect Dis. 2014; 25: 104-6. doi: 10.1016/j.ijid.2014.02.003, PMID: 24865321.

5) Shepard CW, Finelli L, Alter MJ. Global epidemiology of hepatitis C virus infection. Lancet Infect Dis. 2005; 5: 558-67. doi: 10.1016/S1473-3099(05)70216-4.

6) Jou JH, Muir AJ. In the clinic. Hepatitis C. Ann Intern Med. 2012; 157, ITC6-1- ITC6-16. doi: 10.7326/0003-4819-157-11-20121204-01006, PMID: 23208180.

7) Castillo I, Pardo M, Bartolome J, Ortiz-Movilla N, Rodriguez-Inigo E, de Lucas S, et al. Occult hepatitis C virus infection in patients in whom the etiology of persistently abnormal results of liver-function tests is unknown. J Infect Dis. 2004;189: 7-14. doi: 10.1086/380202, PMID: 14702147.

8) Castillo I, Rodriguez-Inigo E, Lopez-Alcorocho JM, Pardo M, Bartolome J, Carreno V. Hepatitis C virus replicates in the liver of patients who have a sustained response to antiviral treatment. Clin Infect Dis. 2006; 43: 1277-83. doi: 10.1086/508198, PMID: 17051492. 
9) Baid-Agrawal S, Schindler R, Reinke P, Staedtler A, Rimpler S, Malik B, et al. Prevalence of occult hepatitis $\mathrm{C}$ infection in chronic hemodialysis and kidney transplant patients. J Hepatol. 2014; 60: 928-33. doi: 10.1016/j.jhep.2014.01.012, PMID: 24447875.

10) Barril G, Castillo I, Arenas MD, Espinosa M, Garcia-Valdecasas J, Garcia- Fernandez N, et al. Occult hepatitis $\mathrm{C}$ virus infection among hemodialysis patients. J Am Soc Nephrol. 2008;19: 2288-92. doi: 10.1681/ASN.2008030293, PMID: 18684893 , PMCID: PMC2588096.

11) Zaghloul H, El-Sherbiny W. Detection of occult hepatitis $C$ and hepatitis B virus infections from peripheral blood mononuclear cells. Immunol Invest. 2010; 39: 284-91. doi: 10.3109/08820131003605820, PMID: 20380524.

12) Welker MW, Zeuzem S. Occult hepatitis C: how convincing are the current data? Hepatology. 2009; 49: 665-75. doi: 10.1002/hep.22706, PMID: 19105211.

13) Pham TN, Coffin CS, Michalak TI. Occult hepatitis C virus infection: what does it mean? Liver Int. 2010; 30: 502-11. doi: 10.1111/j.1478-3231.2009.02193.x, PMID: 20070513.

14) De Marco L, Gillio-Tos A, Fiano V, Ronco G, Krogh V, Palli D, et al. Occult HCV infection: an unexpected finding in a population unselected for hepatic disease. PLoS One. 2009; 4: e8128. doi: 10.1371/journal.pone.0008128, PMID: 19956542, PMCID: PMC2780719.

15) De Marco L, Manzini P, Trevisan M, Gillio-Tos A, Danielle F, Balloco C, et al. Prevalence and follow-up of occult $\mathrm{HCV}$ infection in an Italian population free of clinically detectable infectious liver disease. PLoS One 2012; 7: e43541. doi: 10.1371/journal.pone.0043541, PMID: 22927986, PMCID: PMC3425488.

16) Laskus T, Operskalski EA, Radkowski M, Wilkinson J, Mack WJ, deGiacomo M, et al. Negative-strand hepatitis $\mathrm{C}$ virus (HCV) RNA in prepheral blood mononuclear cells from anti-HCV-positive/HIV infected women. J Infect Dis. 2007; 195(1): 124-33. doi: 10.1086/509897 , PMID: 17152016, PMCID: PMC3319123.

17) Hauser AB, Stinghen AE, Kato S, Bucharles S, Aita C, Yuzawa Y, et al. Characteristics and causes of immune dysfunction related to uremia and dialysis. Perit Dial Int. 2008; 28: S183-7. PMID: 18552253.

18) Fabrizi F, Takkouche B, Lunghi G, Dixit V, Messa P, Martin P. The impact of hepatitis C virus infection on survival in dialysis patients: Meta-analysis of observational studies. J Viral Hepat. 2007; 14: 697-703. doi: 10.1111/j.1365-2893.2007.00868.x, PMID: 17875004.

19) Bokharaei-Salim F, Keyvani H, Monavari SH, Alavian SM, Madjd Z, Toosi MN, et al. Occult Hepatitis C Virus Infection in Iranian Patients With Cryptogenic Liver Disease. J Med Virol. 2011; 83: 989-95. doi: 10.1002/jmv.22044, PMID: 21503911.

20) Thongsawat S, Maneekarn N, Kuniholm MH, Pantip C, Thungsuputi A, Lumlertkul D, et al. Occult hepatitis $\mathrm{C}$ virus infection during an outbreak in a hemodialysis unit in Thailand. J Med Virol. 2008; 80: 808-15. doi: 10.1002/jmv.21126, PMID: 18360894.

21) Fabrizi F, Martin P. Occult hepatitis C virus infection in hemodialysis. J Am Soc Nephrol. 2008; 19:224850. doi: 10.1681/ASN.2008101051, PMID: 19020002.

22) Oesterreicher C, Hammer J, Koch U, Pfeffel F, Sunder-Plassmann G, Petermann D, et al. HBV and HCV genome in peripheral blood mononuclear cells in patients undergoing chronic hemodialysis. Kidney Int. 1995; 48: 1967-71. doi: 10.1038/ki.1995.498, PMID: 8587259.

23) Jadoul M, Cornu C, van Ypersele de Strihou C: Universal precautions prevent hepatitis C virus transmission: A 54 month follow-up of the Belgian Multicenter Study. The Universitaires Cliniques St-Luc (UCL) Collaborative Group. Kidney Int.1998; 53: 1022-25. doi: 10.1111/j.1523-1755.1998.00823.x, PMID: 9551413.

24) CarrenoV, Bartolome J, Castillo I, Quiroga JA. New prespective in occult hepatitis C virus infection. World J Gastroenterol. 2012: 18(23); 2887-94. doi: 10.3748/wjg.v18.i23.2887, PMID: 22736911, PMCID: PMC3380315.

25) Kopkooo PM, Holland PV. Universal leukocyte reduction. Curr Opin Hematol 2000;7:397-401. 